\title{
Simultaneous Decolorization of Methyl Red and Generation of Electricity in Microbial Fuel Cell by Bacillus circulans NPP 1 Jumma Shaikh ${ }^{1}$, Niranjan P Patil ${ }^{1 *}$, Vikas Shinde ${ }^{2}$ and Vishwas B Gaikwad ${ }^{3}$
} ${ }^{1}$ Department of Microbiology, MES's Abasaheb Garware College, Karve Road, Pune, India ${ }^{2}$ Department of Microbiology, Savitribai Phule Pune University, Ganeshkhind, Pune, India ${ }^{3}$ Department of Environmental Sciences, KTHM College, Nashik, India

\begin{abstract}
This study examined azo dye methyl red decolorization in a 2 chambered microbial fuel cell (MFC). The primary objectives of the study were to construct MFC and evaluate methyl red decolorizing and degrading bacterium Bacillus circulans potential in simultaneous decolorization and electricity generation process.

In MFC, both the chambers were connected by Nafion 117 Proton exchange membrane and Graphite electrodes were placed in cathode and anode chamber for optimum electron transfer performance in open circuit system. Under an optimal condition $98 \%$ methyl red $(300 \mathrm{ppm})$ decolorization, $9.9 \mathrm{mg} / \mathrm{l} / \mathrm{h}$ maximum decolorization rate and $856 \mathrm{~mW} / \mathrm{m}^{2}$ maximum power densities were achieved. As compared to traditional anaerobic technology higher decolorization and electricity generation efficiency was achieved by MFC. Bacillus circulans is electrogenic bacteria having potential in MFC technology.
\end{abstract}

Keywords: MFC; Methyl red; Decolorization; Proton exchange membrane; Power density

\section{Introduction}

Azo dyes are major synthetic dyes extensively used in various industries. The process of applying dye on fabric is inefficient due to that; approximately $10-15 \%$ of the dyes are released in to environment producing highly colored wastewater. The first contaminant observed in water is color. The dyes are visible in water even at concentrations as low as $1 \mathrm{ppm}$ [1]. The dyes escape the conventional wastewater treatment process as they are recalcitrant's due to their synthetic origin and complex stable structure (sartale, robinson). Synthetic dyes and their degraded metabolites have various harmful properties like cytotoxic and genotoxic characteristics. The chemical stability of these dye make them resistant to the natural degradation process hence they get deposited and affects aquatic as well as human life. There are various methods are available to treat these dye containing wastewater including physical methods employing precipitation, adsorption, and reverse osmosis, chemical methods such as oxidation (using air, oxygen, ozone, $\mathrm{NaOCl}$ and $\mathrm{H}_{2} \mathrm{O}_{2}$ as oxidants) and reduction $\left(\mathrm{Na}_{2} \mathrm{~S}_{2} \mathrm{O}_{4}\right.$ ); and biological methods such as aerobic and anaerobic treatments. Each of these treatments has special advantages, but intense energy input, sludge formation and the development of toxic intermediates are common challenges that need to be solved before these approaches can be used more widely. Capital costs for biological wastewater treatment processes are 5-20 times less compared to advanced oxidation methods and the running costs are 3-10 times less. In order to reduce cost of treatment, the simultaneous degradation of dye wastewater and generation of electricity using MFCs has achieved considerable attention as an economical and environmentally friendly technique [26]. MFCs are bio-electrochemical devices that use microbes as catalysts to produce electricity by oxidizing organic and inorganic compounds in biomass. MFC convert the chemical energy to electrical energy by means of electrochemically active bacterial decomposition [7]. Bacteria require energy to survive and the consumption of energy occurs in two steps; oxidation which requires the removal of electrons from source of organic matter and reduction which gives electrons to the final electron acceptor, i.e., oxygen. Certain types of bacteria respire by releasing the electrons into the surrounding medium. These released electrons pass through the semi-permeable membrane or agar salt-bridge that connects the two chambers of the MFC. The transferred electrons generate a current and can be used to power devices [8]. A typical MFC contains an anaerobic anode chamber and an aerobic cathode chamber separated by a proton exchange membrane or salt bridge. An external circuit connects the anode and cathode. Theoretically, any compound with sufficiently high redox potentials can serve as a cathodic electron acceptor in an MFC. Thus far, dyes can be used as an alternative cathodic electron acceptor in place of air in MFCs.

This research work aims at evaluating simultaneous dye decolorization and electricity generation potential of bacterium Bacillus circulans isolated from textile effluent treatment plant in MFC.

\section{Materials and Method}

\section{Chemicals, media and bacteria culture}

Methyl red was purchased from Merck India Pvt. Ltd. The microbiological media components were purchase from HiMedia India Pvt. Ltd. The bacterium Bacillus circulans was isolated from dye containing effluent in earlier research work [9]. The reported Bacillus circulans strain is capable degrading 10 different azo dyes.

\section{MFC construction}

The typical MFC consists of two compartments called as anode and cathode respectively. Microbial fuel cell (MFC) was constructed using $8 \mathrm{~mm}$ poly acrylic plastic sheet. Silicon glue was used to stick

*Corresponding author: Niranjan P Patil, Department of Microbiology, MES's Abasaheb Garware College, Karve Road, Pune, India, Tel: 0204103 8200; E-mail: niranjan75@gmail.com

Received September 01, 2016; Accepted September 30, 2016; Published October 07, 2016

Citation: Shaikh J, Patil NP, Shinde V, Gaikwad VB (2016) Simultaneous Decolorization of Methyl Red and Generation of Electricity in Microbial Fuel Cell by Bacillus circulans NPP1. J Microb Biochem Technol 8: 428-432. doi: 10.4172/19485948.1000320

Copyright: $\odot 2016$ Shaikh J, et al. This is an open-access article distributed under the terms of the Creative Commons Attribution License, which permits unrestricted use, distribution, and reproduction in any medium, provided the original author and source are credited. 
various parts to prepare microbial fuel cell. Silicon sealant is used to make MFC leakage proof. The Firm bonding of sealant and silicon glue was developed so that MFC became strong to bear pressure produced inside. Two chambered MFC was constructed. Two half cells were constructed in such way that proton exchange membrane can be fit in between. Nylon rubber used to place proton exchange membrane in between. Nafion 117 is the membrane used to transfer proton from anodic chamber to cathode. Both the compartments were housed with same graphite electrode. The electrode having zero resistance with $0.00306 \mathrm{~m}^{2}$ surface area was used. PEM mainly functions as medium for transfer of proton to make the circuit complete. Proton exchange membrane (PEM) not only completes the reaction process but also prevents anode to come in direct contact with oxygen or any other oxidizers. PEM allow the salt to transfer and increases the efficiency far better than Common Salt Bridge. Appropriate spacing is kept between these 2 electrodes. The total working volume of each chamber was 400 ml. electrical circuit was completed by putting resistance in between the two electrodes. Crocodile clips were used to join resistance to the anode and cathode and one connection is given to the sensitive multimeter (HTC make model-830 L) to measure the electricity being produced by bacteria. Figure 1 shows the schematic of MFC.

\section{MFC operation}

Two types of MFC are discussed in literature viz. mediator less MFC and with mediator MFC. In mediator less MFC there is no need to add any intermediate to the anodic chamber to transfer electrons, because bacteria itself capable of transferring electrons to the electrode. In case of with mediator MFC, bacteria alone are not able to transfer electrons to the anode hence it needs the intermediate like methylene blue, thionine, etc. that can accept the electrons from bacteria and transfer it to the electrode. We used mediator less MFC to evaluate Bacillus circulans potential of transferring electrons to the electrode directly.

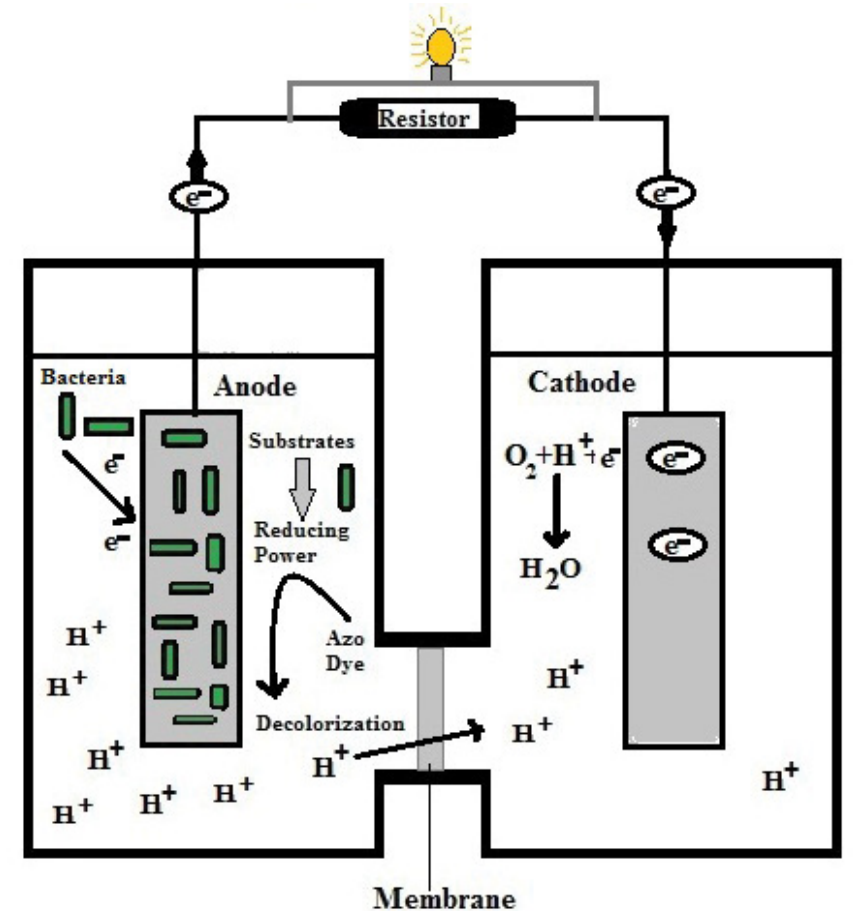

Figure 1: Schematic of two chambers MFC showing dye decolorization and electricity generation processes.
To work with MFC anaerobic condition was maintained in the anode chamber. As there is no electron acceptor other than electrode. Entire operation was done in aseptic condition. MFC was surface sterilized by $70 \%$ ethanol followed by $0.1 \mathrm{HgCl}_{2}$. After giving ethanol and mercuric chloride treatment to the MFC, it is kept in UV chamber for $1 \mathrm{~h}$ to eliminate possibility of contamination. Cathode was filled with $50 \mathrm{mM}$ ferricynide prepared in $0.05 \mathrm{M}$ phosphate buffer. Potassium ferricynide was added as a catholyte. $400 \mathrm{ml}$ nutrient medium containing, $5 \%$ glucose, $0.5 \%$ Yeast extract, $0.5 \%$ Peptone and $300 \mathrm{ppm}$ methyl red was autoclaved and filled in anodic chamber under aseptic condition. The cell suspension $(5 \% \mathrm{v} / \mathrm{v})$ of $0.1 \mathrm{OD}$ at $600 \mathrm{~nm}$ was inoculated by liver biopsy syringe aseptically. This process was run in batch mode. Open electric circuit is used to create flow of electrons. Voltage Potential was measured by multimeter. For determining dye decolorization, $2 \mathrm{ml}$ of sample was aseptically drawn from anode chamber of MFC. The sample was centrifuged at $10000 \mathrm{rpm}$ for $10 \mathrm{~min}$ and absorbance of supernatant was determined at $430 \mathrm{~nm}$ using UV-visible spectrometer. \% Methyl Red decolorization was calculated as given by Waheed et al. [10].

$$
\% \text { Decolorization }=\frac{(\text { Initial absorbance }- \text { Final absorbance }) \times 100}{\text { Initial absorbance }}
$$

\section{Theory of decolorization and electricity generation}

Most of the bacteria form biofilm on the electrodes. Few types of bacteria transfer electrons via nanowire networking. More the biofilm form more efficiently electrons transfer to the electrode. MFC is an extension of the electron transport chain (ETC) where the final step of the process takes place outside the bacterial cell ETC consist of series of components in the bacterial extracellular matrix. Current is the flow of electrons from negative to the positive terminal. In anode compartment bacteria feeds on organic or inorganic compounds and oxidation reaction takes place liberating electrons in anaerobic condition (Figure 2). The electrode accepts this electrons and transfer to the cathode through external electric circuit completing the circuit event. In the process of ETC, NADH is oxidized and forms $\mathrm{NAD}^{+}+\mathrm{H}^{+}$generating 2 electrons and 10 protons. Proton transferred trough PEM to the cathode chamber combines with oxygen and form a water molecule. MFC discovers metabolic potential of microbes for conversion of organic and inorganic substrate into electricity by transferring electron from cell to circuit. In absence of electron acceptor, some microorganism pass electron onto anode either by electron shuttle or by means of electron shuttling mediators. Direct electron transfer to anode by bacteria requires some physical contact

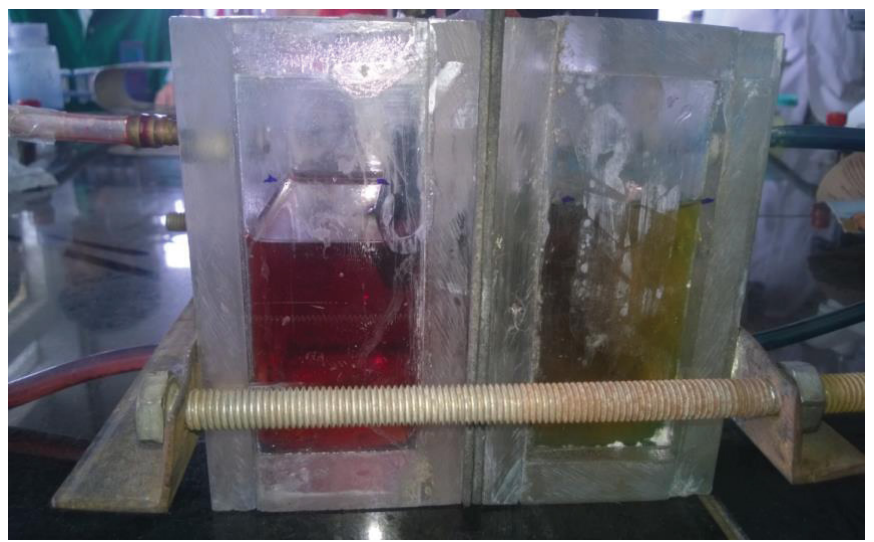

Figure 2: Constructed MFC's anodic chamber containing 300 ppm methyl red (left) and cathodic chamber containing ferricyanide before inoculation. 
with electrode for current generation. Some bacteria carry out azo reduction of colored dye into their colorless counterpart metabolites. Azo reduction need involvement ETC's reduction potential. Electricity generation and azo bond reduction both require common electron donor.

\section{Optimization of parameters}

In order to demonstrate higher efficiency of MFC some of the physicochemical parameters were evaluated one factor at a time approach. The effect of dye concentration (100-500 mg/L) and cosubstrate glucose (0.1-10\%) were assessed.

\section{Calculation and analysis}

The voltage was recorded by using a digital multimeter.

Power, current, current density, and power density was calculated using following formulae. Power calculated by equation:

Power $(P)=I V$

Where $\mathrm{I}=$ current

$\mathrm{V}=$ voltage,

Current $(\mathrm{I})=\mathrm{V} / \mathrm{R}$

Where $\mathrm{R}=$ Resistance

Current density=current $(\mathrm{I}) /$ area of the electrode

Power density=voltage $(\mathrm{v}) \times$ current $(\mathrm{I})$

\section{Results and Discussion}

Figures 3 and 4 shows the photograph of MFC constructed for simultaneous methyl red decolorization and electricity generation. The MFC assembly did not showed leakages after repeated uses, indicating successful construction.

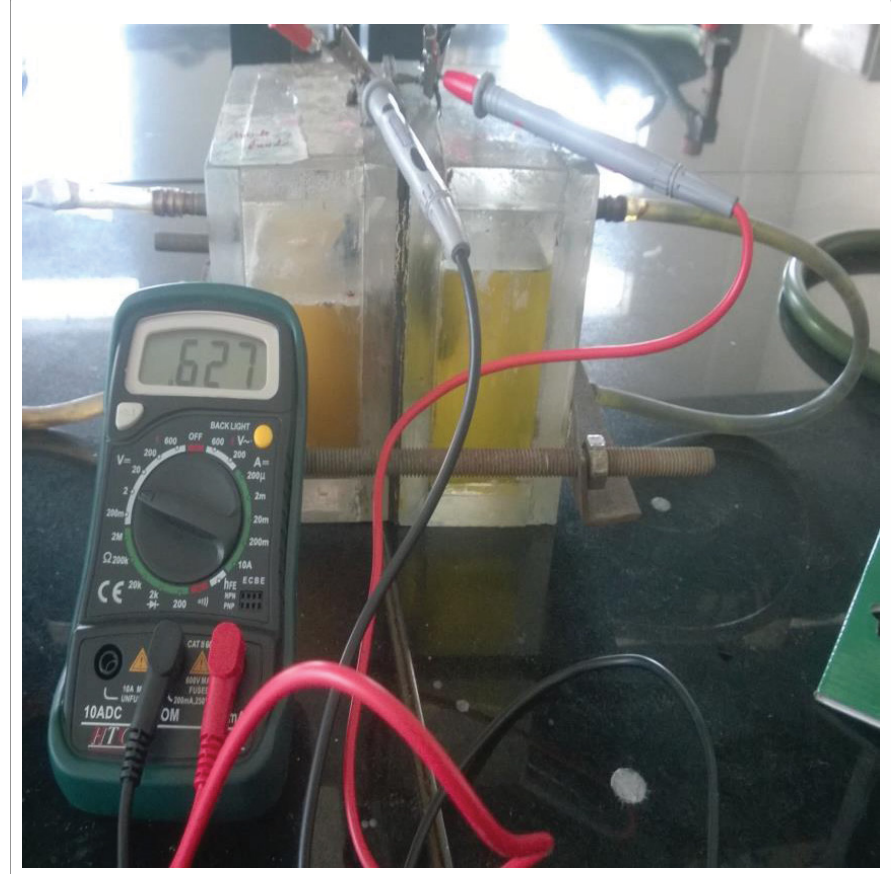

Figure 3: Decolorization of 300 PPM Methyl red dye and electricity production of $627 \mathrm{mV}$ electrical potential after $36 \mathrm{~h}$ of incubation.

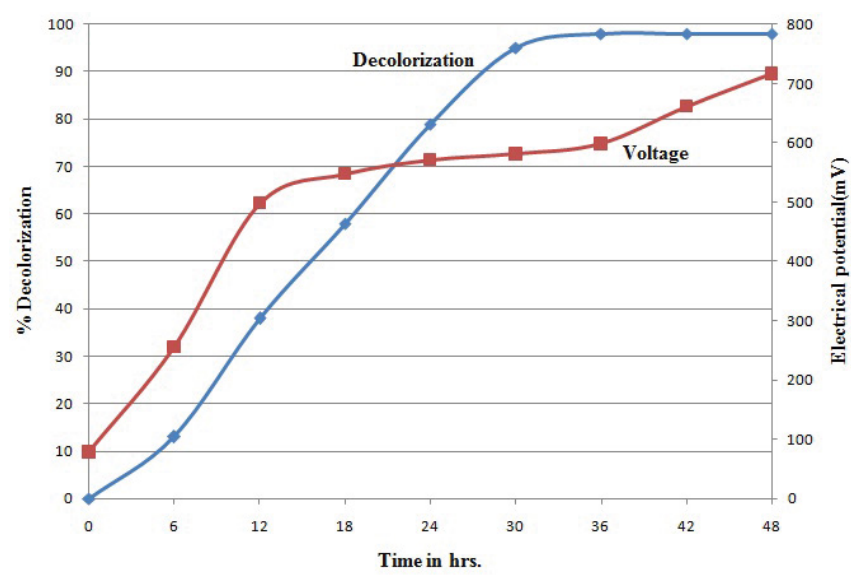

Figure 4: \% Decolorization and electrical potential with respect to time in MFC.

\section{Optimization of parameters}

The two critical factors during operation of MFC are dye concentration and co-substrate concentration was assessed. The other physicochemical factors were chosen based on reported values of earlier research worker. The MFC performance and methyl red decolorization were found to be strictly dependent on the cathodic and anodic conditions, such as $\mathrm{pH}$ of the medium, anaerobic conditions of anode chamber, concentration of catholyte, etc. It was found that 300 ppm methyl red concentration was tolerated by Bacillus circulans without significant effect on decolorization and electricity production. The 400 ppm methyl red and above inhibit cells hence decolorization decreases [10].

The scientific literature indicated that, dye decolorization and electricity generation in MFC enhanced in presence of higher cosubstrate levels Glucose was reported as best co-substrate delivering high performance [11]. In our experiment we found that $5 \%(\mathrm{w} / \mathrm{v})$ glucose support optimum methyl red decolorization and electricity production. As the glucose present in the MFC is in excess and reduction potential required for methyl red decolorization and electricity generation was sufficient for both processes.

\section{Methyl red decolorization and voltage development}

MFC was operated with methyl red containing nutrient medium supporting formation of biomass beside azo dye reduction and electricity production. The production of voltage was monitored for period of $48 \mathrm{~h}$. The measurements were taken following system stabilization after the generation of constant potential. Initial voltage of sterile medium was $78 \mathrm{mV}$; this may be due to biological and chemical factors showing potential difference between two chambers [12]. Experimental data confirmed utility of MFC for methyl red reduction and electricity generation. The performance of MFC with respect to decolorization of methyl red, voltage generation and time of incubation is shown in Figure 4. Initially, steady rise in voltage output was observed. After a lag period of approximately $6 \mathrm{~h}$ after inoculation of the anode chamber, there was an exponential increase in cell voltage over the 12 $\mathrm{h}$, reaching an initial maximum voltage $710 \mathrm{mV}$. The electrode was transferred several times into fresh medium, and each time a stable cycle of voltage generation $(700-710 \mathrm{mV})$ was produced without a lag phase (data not shown). This indicated that bacteria forming biofilm on the electrode were producing electricity and not suspended cells. The $\mathrm{pH}$ of the medium was observed in the range 6.3-7.5. The maximum 
Citation: Shaikh J, Patil NP, Shinde V, Gaikwad VB (2016) Simultaneous Decolorization of Methyl Red and Generation of Electricity in Microbial Fuel Cell by Bacillus circulans NPP1. J Microb Biochem Technol 8: 428-432. doi: 10.4172/1948-5948.1000320

98\% decolorization of 300 ppm methyl red was observed after $36 \mathrm{~h}$. Further decolorization was not increased, due to technical difficulty in recording zero absorption at $\lambda_{\max } 430 \mathrm{~nm}$ of dye as reduced metabolites also contribute some absorbance at that wavelength.

Comparable generation of voltage in MFC using various Bacillus sp. is reported for Bacillus megaterium (max voltage of $698 \mathrm{mV}$ ) and Bacillus subtilis $(691 \mathrm{mV})$ after 8 days of operation $[12,13]$.

Figure 5 show the trend of methyl red decolorization rate and current generation in MFC. After $24 \mathrm{~h}$ of incubation maximum decolorization rate obtained was $9.9 \mathrm{mg} / \mathrm{l} / \mathrm{h}$. The maximum current generated produced was $3.69 \mathrm{~mA}$ after $48 \mathrm{~h}$ of incubation.

The power density is very important parameter for evaluating the performance of MFC for its large scale utilization. Figure 6 represents polarization curve as a function of power density and current density. The maximum power density achieved was $856 \mathrm{~mW} / \mathrm{m}^{2}$. The maximum power density reported by Miran et al. [10] for decolorization of Direct red $80(200 \mathrm{ppm})$ was $477.8 \mathrm{~mW} / \mathrm{m}^{2}$. Also, the maximum power density reported by Guo et al. [2] for decolorization of methyl orange ( $50 \mathrm{ppm})$ was $406 \mathrm{~mW} / \mathrm{m}^{2}$ using microbial communities. Our reported power density is higher than reported due to higher level of co-substrate levels $(5 \% \mathrm{w} / \mathrm{v})$ used in the study. Khan et al. [3] reported $2236 \mathrm{~mW} / \mathrm{m}^{2}$ power density using MFC coupled with activated sludge for decolorization of acid navy blue dye [14-16]. Our power density yield is less than this

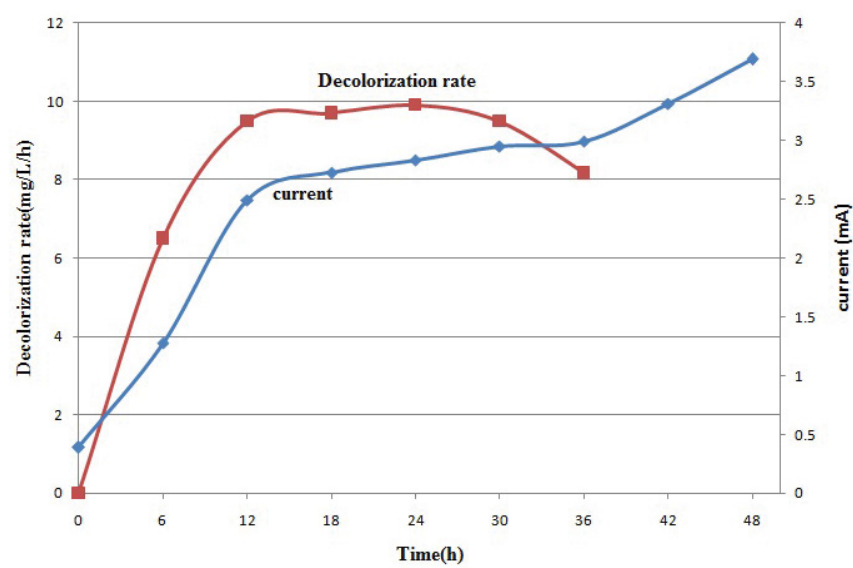

Figure 5: Methyl red decolorization rate and current vs. time in MFC.

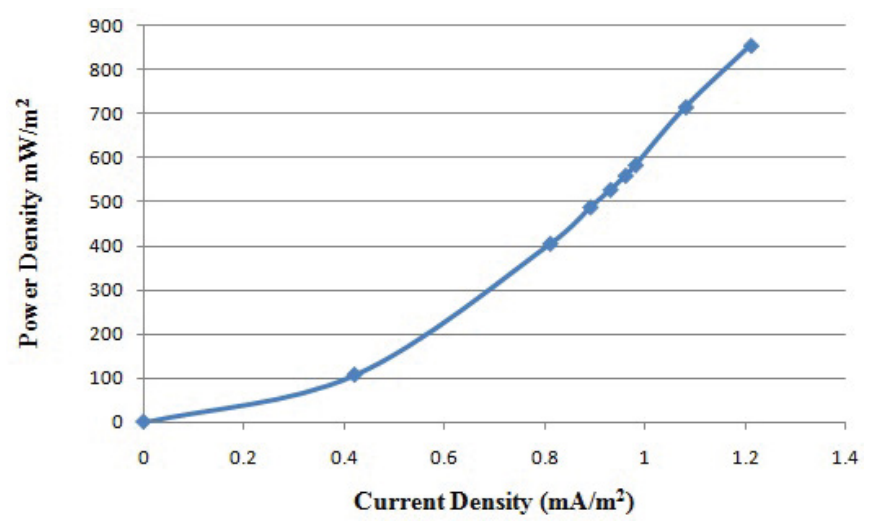

Figure 6: Power density vs. current density in MFC. because work is on the pure culture bacteria and not on the mixed culture.

\section{Conclusion}

Methyl red decolorization with electricity generation has been successfully demonstrated in two chambered MFC using Bacillus circulans. Maximum electricity generation achieved was $710 \mathrm{mV}$ at 200 $\mathrm{ohm}$. The maximum methyl red decolorization achieved was $98 \%$ with $9.9 \mathrm{mg} / \mathrm{L} / \mathrm{h}$. rate of decolorization $300 \mathrm{ppm}$ methyl red concentration and $5 \%$ glucose was used in the medium. The $98 \%$ decolorization of dye and maximum power density produced was $856 \mathrm{~mW} / \mathrm{m}^{2}$ after 48 hr of incubation. Bacillus circulans was found to be able to decolorize MR and produce electricity exhibiting potential in addressing colored wastewater problems. The simultaneous dye decolorization and electricity generation in MFC has promising practical applications.

\section{Acknowledgement}

The author wishes to thank Dr. BD Bhole, Head Department of Microbiology, Abasaheb Garware College, Pune for his encouragement and critical remarks during project work.

\section{References}

1. Banat IM, Nigam P, Singh D, Marchant R (1996) Microbial decolorization of textile dye containing effluents: A review. Bioresour Technol 58: 217-227.

2. Guo Wei, Feng J, Song H, Sun J (2014) Simultaneous bioelectricicty generation and decolorization of methyl orange in a two-chambered microbial fuel cell and bacterial diversity. Environ Sc Pollut Res 21: 11531-11540.

3. Khan MD, Abdulateif H, Ismail IM, Sabir S, Khan MZ (2015) Bioelectricity generation and bioremediation of an azo-dye in a microbial fuel cell coupled activated sludge process. PLoS ONE 10: e0138448.

4. Murali V, Ong SA, Ho LN, Wong YS, Hamidin N (2013) Comprehensive review and compilation of treatment for azo dyes using microbial fuel cells. Water Environ Res 85: 270-277.

5. Galai S, Pérez de los Ríos A, Hernández-Fernández FJ, Kacem SH, Ramírez FM (2015) Microbial fuel cell application for azoic dye decolorization with simultaneous bioenergy production using Stenotrophomonas sp. Chem Eng Technol 38: 1511-1518.

6. Sun J, Hu YY, Bi Z, Cao YQ (2009) Simultaneous decolorization of azo dye and bioelectricity generation using a micro filtration membrane air-cathode single chamber microbial fuel cell. Bioresour Technol 100: 3185-3192.

7. Logan Bruce E, Bert H, Rene R, Uwe S, Jurg K (2006) Microbial fuel cells: Methodology and technology.

8. Zhuwei D, Haoran L, Tingue G (2007) A state of the art on microbial fuel cells: A promising technology for wastewater treatment and bioenergy. Biotechnology Advances 25: 464-482.

9. Patil NP (2010) Studies on bioremediation and biodegradation of dye containing textile effluent PhD Thesis, Savithribai Phule Pune University, Pune, Maharashtra India.

10. Waheed M, Rasool K, Nawaz M, Avinash A, Shin S, et al. (2015) Simultaneous electricity production and direct red 80 degradation using a dual chamber microbial fuel cell desalin. Water Treat 1-9.

11. Solanki K, Subramaniam S, Basu S (2013) Microbial fuel cells for azo dye treatment with electricity generation. A review Bioresource Technology 131 564-571.

12. Nimje VR, Chen CY, Chen CC, Jean JS, Reddy AS (2009) Stable and high energy generation by a strain of Bacillus subtilis in a microbial fuel cell. $J$ Power Sources 190: 258-263.

13. Yoganathan K, Ganesh P (2015) Electrogenicity assessment of Bacillus subtilis and Bacillus megaterium using microbial fuel cell technology. International Journal of Applied Research 1: 435-438.

14. Saratale RG, Saratale GD, Parshetti GK, Chang JS, Govindwar SP (2011) Bacterial decolorization and degradation of azo dyes: A review. J Taiwan Inst Chem Eng 42: 138-157. 
Citation: Shaikh J, Patil NP, Shinde V, Gaikwad VB (2016) Simultaneous Decolorization of Methyl Red and Generation of Electricity in Microbial Fuel Cell by Bacillus circulans NPP1. J Microb Biochem Technol 8: 428-432. doi: 10.4172/1948-5948.1000320

15. dos Santos AB, Cervantes FJ, van Lier JB (2007) Review paper on current technologies for decolorization of textile wastewaters: Perspectives for anaerobic biotechnology. Bioresour Technol 98: 2369-2385.
16. Robinson T, McMullan G, Marchant R, Nigam P (2001) Remediation of dyes in textile effluent: A critical review on current treatment technologies with a proposed alternative. Bioresour Technol 77: 247-255. 